\title{
Editorial: Phoenix on a Tightrope
}

You can't keep a good title down. In July 1975 we reported that the Yugoslav journal Praxis had been suppressed. A press release from Basil Blackwell now brings news of a kind of resurrection:

Praxis International is a new journal committed to the goals of international socialism, and carries on the spirit and work of the Yugoslav journal Praxis on a broader international scale. It will be published quarterly by Basil Blackwell Publisher from April i98I.

The basic purpose of Praxis International is to encourage a forceful. and imaginative critical analysis of existing social systems. It will explore rational alternatives and examine the possibility for democratic social transformation. The editors of Praxis International are Richard J. Bernstein and Mihailo Marković.

The editors do not claim that the new journal is identical with the old one. They report that the eight members of the Praxis group who were suspended by Belgrade University in 1975 have now been dismissed, and that the passport of Mihailo Markovic has been confiscated. They add that 'the community of Praxis continues to function and hopes to resume publication of the journal under more favourable conditions in Yugoslavia'. Meanwhile the new journal 'will develop the critical humanist Marxism that was presented in Praxis', and will be open to 'other non-dogmatic forms of Marxism as well as non-Marxist analyses that are compatible with the basic identity of the journal'. The editors undertake 'to oppose all forms of dogmatic and doctrinaire thought' and 'to encourage dialogues with creative contributions from different and even opposing theoretical trends', so that the journal can foster 'the type of theoretical understanding that is necessary for a relevant imaginative praxis'.

Those who still see a distinction between theory and practice will look forward to watching the acrobatics of this Phoenix on a tightrope. The first issue leans towards unanimity at an angle that no tightrope walker could sustain for long. There are six articles on the main theme, 'Socialism and Democracy', as well as two essays on Herbert Marcuse by Jürgen Habermas ('Psychic Thermidor and the Rebirth of Rebellious Subjectivity') and Richard J. Bernstein ('Negativity: Theme and Variations').

The summer issue of Radical Philosophy notes that Praxis International 'may soon be started outside Yugoslavia'. The aside occurs in a review of Praxis: Yugoslav Essays in the Philosophy and Methodology of the Social Sciences, edited by M. Marković and G. Petrović. On another page of Radical Philosophy there is an advertisement for Praxis: A Fournal of 


\section{Editorial}

Cultural Criticism, originating in Santa Monica, California. Phoenixes are becoming so frequent that Radical Philosophy should think of changing its own name to Praxis. We all know what happened to the Monty Python hero who found himself in an Australian Philosophy Department although his name wasn't Bruce. 